\title{
ANALISIS FATWA DSN-MUI NOMOR 25/III/2002 TERHADAP PENETAPAN UJRAH DALAM AKAD RAHN DI BMT UGT SIDOGIRI CABANG WARU SIDOARJO
}

\author{
M. Zainuddin Alanshori \\ Universitas Islam Lamongan \\ e-mail: zen.120888@gmail.com
}

\begin{abstract}
Sharia financial institutions are financial institutions that not only prioritize profit oriented, but also a financial institution that also puts the public good in accordance with the demands of sharia which is the foundation of all Islamic financial institutions. One application is to implement a moral and spiritual based service. This field research will answer the question. First, how is application of ujrah determination in contract of rahn in BMT UGT Branch Sidogiri Waru Sidoarjo? The second, how is the analysis of the DSN-MUI fatwa NUMBER 25/III /2002 on the determination of ujrah in the contract of rahn in BMT UGT Branch Sidogiri Waru Sidoarjo? Data collection techniques used are interview, document review, and observation, then analyzed by using descriptive analysis method, with deductive thought pattern, that is theory of rahn, ijarah, and fatwa of National Sharia Council (DSN) with general characteristics and then linked with the facts on the ground about the fatwa of DSN-MUI NUMBER 25/III/2002 on the establishment of ujrah in the contract of rahn in BMT UGT Branch Sidogiri Waru Sidoarjo with special characteristics. From the results of the study, the author concludes the application of the determination of ujrah in the covenant of rahn in BMT UGT Branch Sidogiri Waru Sidoarjo, namely the determination of ujrah through two contracts, namely rahn and ijarah contract. The procedures for the implementation of the contract are as follows: Rahin (customer) comes to murtahin (BMT) while delivering marhun (collateral goods) then the goods will be estimated. As a result of this, the rahin will be subject to administrative costs. Then rahin signs the agreement or contract of rahn. After that, to entrust the goods hock, rahin must implement contract of ijarah (contract to rent place). Consequently it arise ujrah. In this case, it means that customer must implement two barrage of contract. The determination of ujrah applied in BMT is not in accordance with the Fatwa DSN-MUI NO: 25/DSN-MUI/ III/2002 because the determination of ujrah is determined from the amount of the customer's loan, while the difference is the discount given to the customer for applying smaller loan. The determination of discount is determined from ujrah or ijarah fee charged to the customer. This discount is calculated based on the percentage of estimated value of customer's loan amount.
\end{abstract}

Keywords: ujrah determination, rahn contract, DSN-MUI fatwa

\section{Pendahuluan}

Manusia dalam hidupnya senantiasa akan memerlukan manusia lain karena pada hakikatnya manusia adalah makhluk sosial. Dalam kehidupan sehari-hari, manusia sangat memerlukan manusia lain untuk dapat saling tolong menolong antara satu dengan yang lainnya. Tolong menolong yang baik bersifat menguntungkan kedua belah pihak dan tidak mengingkari salah satu pihak. Sebagaimana firman Allah: 


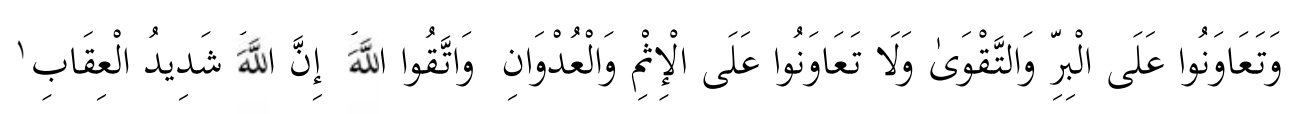

"Dan tolong menolonglah kamu dalam (mengerjakan) kebajikan dan taqwa, dan jangan tolong-menolonglah dalam berbuat dosa dan permusuhan dan bertakwalah kamu kepada Allah, Sesungguhnya Allah amat berat siksa-Nya."2

Perintah tolong menolong dalam kebaikan sesuai ayat yang telah dijelaskan di atas meliputi semua aspek kehidupan yakni sosial, politik, budaya, dan ekonomi.

Dalam persoalan ekonomi khususnya yang berprinsip syariah juga bermacam-macam, diantara jenis kerja sama dan tolong menolong yang telah membudaya di kalangan masyarakat adalah pinjam meminjam dan utang-piutang. Bentuk kerjasama tersebut banyak diwujudkan melalui lembaga keuangan baik bank maupun non bank.

Berdirinya lembaga keuangan syariah yang terus mengalami perkembangan pesat membawa andil yang sangat baik dalam tatanan sistem keuangan di Indonesia. Peran ini tentu saja sebagai upaya untuk mewujudkan sistem keuangan yang adil, oleh karena itu keberadaannya perlu mendapat dukungan dari segenap lapisan masyarakat muslim.

Lembaga keuangan syariah merupakan lembaga keuangan yang tidak hanya mengedepankan profit oriented saja, melainkan suatu lembaga keuangan yang juga mengedepankan kemaslahatan masyarakat sesuai dengan tuntutan syariah yang menjadi landasan dari semua lembaga keuangan syariah. Salah satu aplikasinya adalah menerapkan pelayanan yang berbasis moral dan spiritual.

Bank syariah sebagai salah satu lembaga keuangan mempunyai peranan penting dalam kehidupan suatu negara, apalagi untuk negara yang sedang berkembang seperti Indonesia. Peran strategis tersebut terutama disebabkan oleh fungsi utama bank sebagai lembaga yang dapat menghimpun dan menyalurkan dana kepada masyarakat secara efektif dan efisien.

Dengan berperan sebagai lembaga intermediasi yang berfungsi untuk mengarahkan dana dari masyarakat yang mempunyai kelebihan dana, kemudian menyalurkan dana-dana tersebut kepada masyarakat yang kekurangan dana. Dalam hal ini penyaluran dana di bank syariah berupa fasilitas pembiayaan. ${ }^{3}$ Bagi masyarakat yang mempunyai kekhawatiran adanya bunga bank (riba), maka bank syariah bisa menjadi alternatif yang lebih inovatif sebagai sarana peminjaman modal ataupun menginvestasikan dana. Hal inilah yang membedakan sistem perbankan syariah dengan perbankan konvensional, sebagaimana firman Allah:

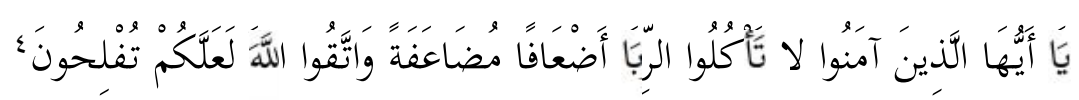

"Hai orang-orang yang beriman janganlah kamu memakan riba dengan berlipat ganda dan bertakwalah kamu pada Allah supaya kamu mendapatkan keuntungan". 5

\footnotetext{
1 al-Quran, 5: 2.

${ }^{2}$ Departemen Agama RI, Al-Qur'an dan Terjemahannya (Jakarta: Widya Cahaya, 2009), 156-157.

${ }^{3}$ Sutan Remi Sjahdeini, Perbankan Islam dan Kedudukannya Dalam Tata hukum Perbankan Indonesia (Jakarta: Pustaka Utama Grafita, 1999), 1.

${ }^{4}$ al-Quran, 3: 130.

${ }^{5}$ Departemen Agama RI, Al-Qur'an dan Terjemahannya (Jakarta: PT Rilis Grafika, 2009), 66.
} 
Akan tetapi untuk dapat mengakses sumber pendanaan dari bank syariah, bagi masyarakat menengah ke bawah dan pengusaha mikro mengalami kesulitan. Hal ini dikarenakan sistem dan prosedur perbankan yang terkesan rumit, sehingga mereka tidak mampu untuk memenuhi prosedur tersebut.

Di Indonesia lembaga-lembaga yang mendukung kemajuan ekonomi telah banyak berdiri, salah satunya adalah lembaga keuangan syariah. Keberhasilan perekonomian suatu masyarakat dapat dicapai antara lain melalui lembaga keuangan syariah, terutama dalam dunia modern saat ini. Lembaga keuangan syariah telah menjadi bagian dari kegiatan kehidupan perekonomian masyarakat. Lembaga keuangan syariah berperan dalam usahausaha pembangunan ekonomi, guna meningkatkan taraf hidup kehidupan manusia.

Menurut Subagio, lembaga keuangan syariah mempunyai fungsi antara lain:

1. Melancarkan pertukaran produk (barang dan jasa) dengan menggunakan uang dan instrumen kredit.

2. Menghimpun dana dari masyarakat dalam bentuk simpanan dan menyalurkan kepada masyarakat dalam bentuk pinjaman.

3. Memberikan pengetahuan tentang tugas-tugas lembaga keuangan dan informasi yang berguna untuk menguntungkan bagi nasabah.

4. Lembaga keungan syariah memberikan jaminan hukum dan moral mengenai keamanan dan masyarakat yang dipercayakan kepada lembaga keuangan tersebut.

5. Lembaga keuangan syariah mampu memberikan keyakinan kepada nasabahnya bahwa dana yang dihimpun akan dikembalikan pada waktu yang ditentukan atau pada waktu jatuh tempo. ${ }^{6}$

Dilihat dari fungsi lembaga keuangan syariah di atas maka upaya yang paling tepat membantu golongan ekonomi lemah adalah menyediakan sumber modal yang dapat menambah modal usaha mereka, misalkan menggunakan jaminan maka yang perlu diperhatikan adalah usaha yang perlu untuk dibiayai.

Didorong oleh rasa keprihatinan pada kondisi tersebut, akhirnya pada tahun 1992 lahirlah sebuah lembaga keuangan kecil yang beroperasi dengan menggunakan gabungan antara konsep bayt al-ma $\triangleright$ dan bayt al-tamwit, yang mana target, sasaran, serta skalanya diutamakan pada sektor usaha mikro dan masyarakat menengah ke bawah. Lembaga tersebut bernama bayt al-ma\$bayt al-tamwi yang disingkat menjadi BMT. ${ }^{7}$ BMT sebagai lembaga keuangan yang ditumbuhkan dari peran masyarakat secara luas, tidak ada batasan ekonomi, sosial, bahkan agama. Semua komponen masyarakat dapat berperan aktif dalam membangun sebuah system keuangan yang lebih adil dan yang lebih penting mampu menjangkau lapisan pengusaha yang terkecil sekalipun. ${ }^{8}$

Secara konseptual, BMT adalah sebuah lembaga yang di dalamnya mencakup dua jenis kegiatan sekaligus, yaitu sebagai bayt al-ma dan sekaligus bayt al-tamwi $\gg$. Menurut fungsinya, bayt al-ma bertugas untuk menghimpun, mengelola, dan menyaluran dana zakat, infak, dan sedekah (ZIS), sehingga pada fungsi ini lebih menekankan pada aspek sosial

\footnotetext{
6 Subagio, Bank dan Lembaga Keuangan Lainnya (Yogyakarta: Bagian Penerbitan Sekolah Tinggi Ilmu Ekonomi YKPM, 1997), 4.

${ }^{7}$ Jamal Lulail Yunus, Manajemen Bank Syariah Mikro (Malang: UIN-Malang Press, 2009$), 7$.

${ }^{8}$ Muhammad Ridwan, Manajemen Baitul Maal Wa Tamwil (BMT) (Yogyakarta: UII Press, 2005), 73.
} 
(tabarru'). ${ }^{9}$ Sedangkan bayt al-tamwi bertugas sebagai lembaga bisnis yang memfokuskan kegiatan usahanya pada sektor keuangan. Sebagai lembaga bisnis, BMT lebih mengembangkan usahanya pada simpan-pinjam. Usaha ini seperti usaha perbankan yakni menghimpun dana anggota dan calon anggota (nasabah) serta menyalurkannya pada sektor ekonomi yang halal dan menguntungkan. ${ }^{10}$

BMT UGT Sidogiri (Bayt al-Ma Bayt al-Tamwi Usaha Gabungan Terpadu) didirikan oleh beberapa pengurus BMT dan orang-orang yang berada dalam satu kegiatan UGT-PPS (Urusan Guru Tugas Pondok Pesantren Sidogiri). Salah satu cabang BMT UGT Sidogiri yang tersebar di Jawa Timur adalah BMT UGT Sidogiri Cabang Waru Sidoarjo. Banyak produk yang ditawarkan oleh BMT UGT Sidogiri, salah satunya adalah produk pembiayaan rahn. ${ }^{11}$

Undang-Undang Nomor 10 pasal 1 Tahun 1998 menyebutkan bahwa pembiayaan berdasarkan prinsip syariah adalah penyediaan uang atau tagihan yang dipersamakan dengan itu berdasarkan persetujuan atau kesepakatan antara bank dengan pihak lain yang mewajibkan pihak yang dibiayai untuk mengembalikan uang atau tagihan tersebut setelah jangka waktu tertentu dengan imbalan atau bagi hasil. ${ }^{12}$

Pembiayaan rahn (gadai) adalah menahan salah satu harta milik si peminjam sebagai jaminan atas pinjaman yang diterimanya. Barang yang ditahan tersebut memiliki nilai ekonomis, dengan demikian pihak yang menahan memperoleh jaminan untuk dapat mengambil kembali seluruh atau sebagian piutangnya. ${ }^{13}$ Dalam akad rahn, terdapat biaya pemeliharaan atau penyimpanan (ujrah), yakni merupakan biaya yang dibutuhkan untuk merawat barang gadaian selama jangka waktu pada akad gadai. sebagaimana firman Allah:

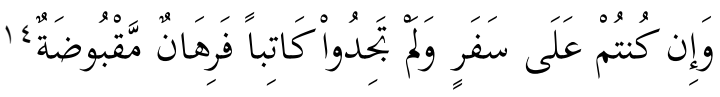

"Jika kamu berada dalam perjalanan (dan bermuamalah tidak secara tunai) sedangkan kamu tidak memperoleh seorang penulis, maka hendaklah ada barang tanggungan yang dipegang (oleh yang berpiutang)". ${ }^{15}$

Dalam teorinya, rahn menjadikan suatu benda bernilai menurut pandangan Islam sebagai tanggungan utang, dengan adanya benda yang menjadi tanggungan itu, maka seluruh atau sebagian tanggungan utang, dengan adanya benda yang menjadi tanggungan itu, maka seluruh atau sebagian utang dapat diterima. ${ }^{16}$ Sedangkan ujrah adalah ongkos atau pengorbanan materi yang dikeluarkan oleh bank dalam hal pelaksanaan akad gadai dengan penggadai (ratin). ${ }^{17}$ Karena biaya administrasi merupakan ongkos yang dikeluarkan bank, maka pihak bank yang lebih mengetahui dalam menghitung rincian biaya administrasi.

\footnotetext{
${ }^{9}$ Hertanto Widodo dkk, Panduan Praktis Operasional Baitul Mal Wat Tamwil (BMT) (Bandung: Mizan, 1999), 36.

${ }^{10}$ Muhammad Ridwan, Manajemen Baitul Maal, 126.

${ }^{11}$ Muzani,Wawancara, Sidoarjo, 22 Mei 2014.

${ }^{12}$ Ibid.

${ }^{13}$ Muhammad Syafi'i Antonio, Bank Syariah Dari Teori Ke Praktik (Jakarta: Gema Insani, 2009), 101.

14 al-Quran, 2:283.

${ }^{15}$ Departemen Agama RI, Al-Qur'an dan Terjemahannya, 49.

${ }^{16}$ Ahmad Azhar Basir, Hukum Islam Tentang Riba, Utang Piutang Gadai, (Bandung: al-Ma'arif, 1983 ), 50.

${ }^{17}$ Muzani, Wawancara, Sidoarjo, 24 Mei 2014.
} 
Setelah bank menghitung total biaya administrasi, kemudian nasabah atau penggadai mengganti biaya administrasi tersebut. ${ }^{18}$

Namun, tidak banyak atau bahkan sangat jarang nasabah yang mengetahui rincian biaya administrasi tersebut. Bank hanya menginformasikan total biaya administrasi yang harus ditanggung oleh nasabah atau penggadai tanpa menyebutkan rinciannya. Keterbukaan dalam menginformasikan rincian biaya administrasi tersebut sangat penting dalam rangka keterbukaan yang kaitannya dengan rid $l>b i$ al-rid $\ell_{l}>$ karena biaya administrasi tersebut dibebankan kepada nasabah atau penggadai.

Dalam Fatwa Dewan Syariah Nasional (DSN) Nomor 25/DSN-MUI/III/2002 disebutkan bahwa besar biaya pemeliharaan dan penyimpanan marhuæ tidak boleh ditentukan berdasarkan jumlah pinjaman. Artinya penggadai harus mengetahui besar rincian dan pengeluaran apa saja yang dikeluarkan oleh bank untuk melaksanakan akad gadai, tetapi ujrah yang ada di BMT UGT Sidogiri Cabang Waru Sidoarjo berbeda dengan BMT pada umumnya. BMT UGT Sidogiri Cabang Waru Sidoarjo menerapkan ujrah dengan menentukan berdasarkan besar kecilnya jumlah pinjaman oleh nasabah, semakin besar jumlah pinjamanya maka ujrahnya semakin besar, begitu pula sebaliknya semakin kecil pinjamanya maka ujrahnya semakin kecil. ${ }^{19}$

Pembiayaan rahn memberikan banyak manfaat kepada BMT UGT Sidogiri. Salah satunya adalah keuntungan yang muncul dari selisih jumlah pinjaman dari nasabah. Meskipun begitu, pembiayaan rahn juga memiliki resiko yang tidak kecil. Anggota terkadang merasa keberatan, karena pada dasarnya dalam menentukan ujrahnya tidak boleh berdasarkan kepada jumlah pinjaman. Misal, dua anggota mengunakan akad rahn dengan membawa motor yang sama dilihat dari segi barang dan nilai ekonomisnya, yang satu melakukan pinjaman sebesar Rp. 3.000.000,- dan yang satunya melakukan pinjaman sebesar Rp. 5.000.000,- dari anggota yang melakukan pinjaman yang kecil dikenakan ujrah lebih sedikit dibandingkan yang melakukan pinjaman yang besar meskipun barang yang mereka gadaikan merupakan barang yang sama dari segi nilai jualnya. ${ }^{20}$

\section{Aplikasi Rahn dalam Lembaga Keuangan Syariah}

Operasi pegadaian syariah menggambarkan hubungan di antara nasabah dan pegadaian. Adapun teknis pegadaian syariah adalah sebagai berikut: ${ }^{21}$

1. Nasabah menjaminkan barang kepada pegadaian syariah untuk mendapatkan pembiayaan. Kemudian pegadaian menaksir barang jaminan untuk dijadikan dasar dalam memberikan pembiayaan.

2. Pegadaian syariah dan nasabah menyetujui akad gadai.

3. Pegadaian syariah menerima biaya gadai, seperti biaya penitipan, biaya pemeliharaan, penjagaan dan lainnya.

4. Nasabah menebus barang yang digadaikan setelah jatuh tempo.

\footnotetext{
${ }^{18}$ Ibid.

${ }^{19}$ Ibid.

${ }^{20} \mathrm{Ibid}$.

${ }^{21}$ Muhammad Syafi'i Atonio, Bank Syariah dari Teori, 66
} 


\section{Berakhirnya Perjanjian Rahn}

Menurut ketentuan syariat bahwa apabila masa yang telah diperjanjikan untuk pembayaran utang telah dilewati maka si berhutang berkewajiban untuk membayar hutangnya. Namun si berhutang tidak mempunyai kemauan untuk mengembalikan pinjamannya hendaklah ia memberikan izin kepada pemegang gadai untuk menjual barang gadaian. Dan seandainya izin ini tidak diberikan oleh si pemberi gadai maka si penerima gadai dapat meminta pertolongan hakim untuk memaksa si pemberi gadai untuk melunasi hutangnya atau memberikan izin kepada si penerima gadai untuk menjual barang gadai tersebut. Akad rahn berakhir dengan hal-hal sebagai berikut: ${ }^{22}$

1. Barang diserahkan kembali kepada pemiliknya.

2. Ratin membayar hutangnya.

3. Dijual dengan perintah hakim atas perintah ratin.

4. Pembebasan hutang dengan cara apapun, meskipun tidak ada persetujuan dari pihak ratin.

\section{Mekanisme Ujrah}

Dalam pengupahan terdapat dua sistem, yaitu sistem pengupahan dalam pekerjaan dan ibadah.

1. Upah dalam ibadah

Upah dalam perbuatan ibadah atau ketaatan, seperti dalam shalat, puasa, haji dan membaca al-Quran diperselisihkan kebolehannya oleh para ulama karena berbeda cara pandangan terhadap pekerjan pekerjaan ini.

Mazhab Syafi'i dan Maliki membolehkan mengambil upah sebagai imbalan mengajar al-Quran dan ilmu-ilmu, karena ini termasuk jenis imbalan perbuatan yang diketahui dan tenaga yang diketahui pula. Ibn Hazm mengatakan bahwa pengambilan upah sebagai imbalan mengajar al-Quran dan pengajaran ilmu baik secara bulanan atau sekaligus karena nas \}yang melarang tidak ada. ${ }^{23}$

2. Sistem pengupahan pekerjaan yang bersifat materi

Dalam melakukan pekerjaan dan besarnya pengupahan seseorang itu ditentukan melalui standar kompetensi yang dimilikinya, yaitu: ${ }^{24}$

a. Kompetensi teknis, yaitu pekerjaan yang bersifat keterampilan teknis, contoh pekerjaan berkaitan dengan mekanik perbengkelan, pekerjaan di proyek-proyek yang bersifat fisik, pekerjaan dibidang industri mekanik lainnya.

b. Kompensasi sosial yaitu, pekerjaan yang bersifat hubungan kemanusiaan. Seperti pemasaran, hubungan kemasyarakatan, dan lain-lain.

c. Kompetensi manegerial, yaitu pekerjaan yang bersifat penataan dan pengaturan usaha, seperti manager keuangan dan lainnya.

d. Kompensasi intelektual, yaitu tenaga di bidang perencanaan, konsultan, dosen, guru, dan lainnya.

\footnotetext{
${ }^{22}$ Hendi Suhendi, Fiqih Muamalah (Jakarta: Raja Grafindo Persada, 2005), 179.

${ }^{23}$ Rachman Syafe'i, Fiqih Muamalah, 127.

${ }^{24}$ Ismail Nawawi, Fiqh Muamalah (Surabaya: Vira Jaya Multi Press, 2009), 89-93.
} 


\section{Ketentuan Fatwa Dewan Syariah Nasional (DSN) tentang Akad Rahn}

Dewan Syariah Nasional (DSN) merupakan sebuah lembaga yang berada di bawah naungan Majelis Ulama Indonesia (MUI), yang dipimpin oleh Ketua Umum MUI. Fungsi utama Dewan Syariah Nasional (DSN) adalah mengawasi produk-produk lembaga keuangan syariah agar sesuai dengan syariat Islam. ${ }^{25}$ Untuk keperluan pengawasan, Dewan Syariah Nasional (DSN) membuat garis panduan produk syariah yang diambil dari sumber-sumber hukum Islam. Garis panduan ini menjadi dasar pengawasan bagi Dewan Syariah Nasional (DSN) pada lembaga-lembaga keuangan syariah dan menjadi dasar pengembangan produkproduknya. ${ }^{26}$ Yang dimaksud garis panduan produk syariah adalah fatwa Dewan Syariah Nasional (DSN). Fatwa Dewan Syariah Nasional (DSN) merupakan Peraturan dan ketentuan yang berkenaan dengan semua kegiatan dalam lembaga keuangan syariah.

Adapun fatwa Dewan Syariah Nasional (DSN) yang berkaitan dengan penelitian penulis adalah fatwa Dewan Syariah Nasional (DSN) Nomor 25/DSN-MUI/III/2002 tentang rahn:

Ketentuan Umum:

1. Murtahin (penerimah barang) mempunyai hak untuk menahan marhuæ (barang) sampai semua hutang rałin (yang menyerahkan barang) dilunasi.

2. Marhuæ dan manfaatnya tetap menjadi milik ratin. Pada prinsipnya, marhuæ tidak boleh dimanfaatkan oleh murtahin tanpa seizin ratin, dengan tidak mengurangi nilai marhun dan pemanfaatnya itu tidak sekedar penganti biaya pemeliharaan dan perawatanya.

3. Pemeliharaan dan penyimpanan marhun pada dasarnya menjadi kewajiban ratein, namun dapat dilakukan juga oleh murtahin, sedangkan biaya pemeliharaan penyimpanan tetap menjadi kewajiban ratin.

4. Besar biaya pemeliharaan dan penyimpanan marhuæ tidak boleh ditentukan oleh jumlah besar pinjaman.

5. Penjualan marhuæ

a. Apabila jatuh tempo, murtahin harus memperingatkan rabin untuk segera melunasi hutangnya.

b. Apabila ratein tetap saja tidak bisa melunasi hutangnya, maka marhuæ dijual paksa/dieksekusi melalui lelang syariah.

c. Hasil penjualan marhuæ digunakan untuk melunasi hutang, biaya pemeliharaan dan penyimpanan yang belum dibayar serta biaya penjualan.

d. Kelebihan hasil penjualan menjadi milik rałin dan kekurangannya menjadi kewajiban rałin.

Ketentuan penutup:

1. Jika salah satu pihak tidak menunaikan kewajibanya atau jika terjadi perselisihan diantara para pihak, maka penyelesainya dilakukan melalui Badan Arbitrase Syariah setelah tidak tercapai kesepakatan melalui musyawarah.

2. Fatwa ini berlaku sejak ditetapkan, dengan ketentuan jika dikemudian hari terdapat kekeliruan, akan diubah dan disempurnakan sebagai semestinya. ${ }^{27}$

\footnotetext{
${ }^{25}$ Bank Indonesia, Petunjuk Pelaksanaan Pembukaan Kantor Bank Syariah (Jakarta: Bank Indonesia, 1999), 22.

${ }^{26}$ Ibid., 24.

${ }^{27}$ Yeni Salma Barlinti, Kedudukan Fatwa Dewan Syariah Nasional dalam Sistem Hukum Nasional di Indonesia (Jakarta: Badan Litbang dan Diklat Kementerian Agama RI, 2010), 406.
} 


\section{Sejarah Singkat Berdirinya BMT UGT Sidogiri Cabang Waru Sidoarjo}

Untuk mengetahui sejarah berdirinya BMT-UGT Sidogiri Cabang Waru Sidoarjo, maka kita harus melihat sejarah berdirinya BMT Sidogiri. Sejarah berdirinya BMT Sidogiri dilatarbelakangi oleh rasa keprihatinan para ustadz alumni Sidogiri yang masuk dalam pengurus Urusan Guru Tugas (UGT) akan merebaknya prakter riba yang terjadi di sekitar Pondok Sidogiri. Praktek riba ini terjadi karena tidak adanya lembaga keuangan yang berlandaskan sistem syariah yang dapat meminjamkan modal usaha kepada mereka (masyarakat sekitar Pondok Sidogiri). Sehingga mudah bagi para rentenir untuk masuk dalam kehidupan mereka, dan menyebabkan praktek riba.

Berbekal dari rasa prihatin itu setelah mendapat izin dari pengasuh pondok dan berbekal dari pengalaman mengikuti seminar tentang BMT dalam acara perkoperasian yang diselenggarakan di pondok pesantren yang diasuh oleh Kyai Zainul Hasan Genggong Probolinggo, maka pada tanggal 12 Robiul Awal $1418 \mathrm{H}$ atau 17 Juli 1997 M berdirilah BMT Sidogiri pertama yang bernama BMT Maslał Mursalah\}Lil Ummah (MMU). Seiring berjalannya waktu pada tanggal 4 September 1997, disahkanlah BMT MMU Pasuruan sebagai Koperasi Serba Usaha dengan Badan Hukum Koperasi Nomor 608/BH/KWK.13/IX/97. ${ }^{28}$

Kehadiran BMT ini mendapatkan respon positif dari masyarakat sekitar pondok. Karena dengan adanya BMT ini, masyarakat tidak lagi khawatir akan adanya praktek riba yang terjadi di masyarakat dan tidak terjerat hutang dari para rentenir.

Koperasi UGT Sidogiri (Baitul Maßwat TamwißUsaha Gabungan Terpadu) didirikan oleh beberapa pengurus BMT-MMU dan orang-orang yang berada dalam satu kegiatan UGTPPS (Urusan Guru Tugas Pondok Pesantren Sidogiri) yang didalamnya terdapat PJGT, Pimpinan Madrasah, Guru, Alumni dan Partisipan PPS yang tersebar di Jawa Timur.

Kemudian pada tahun 2000 para pengurus BMT Sidogiri ingin mengembangkan misinya ke seluruh Indonesia, yang mana daerah tersebut ada alumni dari pondok Sidogiri. Pembukaan cabang pertama bertempat di Surabaya. Pembukaan BMT Sidogiri Cabang Surabaya diberi nama BMT Usaha Gabungan Terpadu (UGT) Sidogiri. Kemudian tempat ke dua bertempat di Jember, dan hal itu berlanjut hingga sekarang. Sehingga BMT-UGT Sidogiri telah membuka cabang sebanyak 176 unit layanan BMT dan 1 unit layanan transfer. ${ }^{29}$

\section{Realisasi Penetapan Ujrah dalam Akad Rahn di BMT UGT Sidogiri Cabang Waru Sidoarjo}

Realisasi penetapan ujrah dalam akad rahn adalah gambaran nyata pada nasabah yang melakukan pembiayaan. Pada kenyataan yang ada dengan adanya penetapan ujrah tersebut, meskipun barang yang diserahkan nasabah kepada pihak BMT itu sama dalam harga jual dipasaran, akan tetapi tidak menjadi patokan dalam penetapan ujrah, pihak BMT melakukan penetapan ujrah berdasarkan atas jumlah pinjaman yang dilakukan oleh nasabah. ${ }^{30}$

Berikut profil beberapa nasabah yang telah melakukan pembiayaan rahn di BMT UGT Sidogiri Cabang Waru Sidoarjo. Pertama, yakni Bapak Zainal, profesinya sebagai pengusaha

\footnotetext{
${ }^{28}$ Dokumen BMT UGT Sidogiri.

${ }^{29}$ Ibid.

${ }^{30}$ Muzani, Wawancara, Sidoarjo, 25 Juni 2014.
} 
bengkel motor. Beliau sudah sekitar dua tahun menjadi nasabah BMT UGT Sidogiri Cabang Waru Sidoarjo. Untuk mendapatkan modal tambahan untuk peralatan bengkelnya beliau melakukan pinjaman sebesar Rp. 5.000.000.- ${ }^{31}$ Kemudian yang kedua yakni Bapak Suparno, profesinya sebagai pedagang warung. Beliau sudah tiga tahun menjadi nasabah BMT UGT Sidogiri Cabang Waru Sidoarjo. Beberapa tahun yang lalu beliau mendapat cobaan yakni anak beliau terkena penyakit kanker darah, sehingga membutuhkan dana yang tidak sedikit untuk pengobatan anaknya dan beliau melakukan pinjaman sebesar Rp. 7.000.000.- kepada pihak BMT. ${ }^{32}$ Kedua nasabah tersebut melakukan pembiayaan dengan membawa motor Supra x 125 dengan tahun yang sama, yakni tahun 2011 sebagai barang jaminan untuk melakukan pinjaman. Pihak BMT lalu memberikan pinjaman kepada kedua nasabah tersebut dengan tempo pengembalian pinjaman yang telah disepakati, akan tetapi jumlah pinjaman yang dilakukan oleh Bapak Suparno itu ujrahnya lebih besar dibandingkan dengan bapak Zainal. Karena Bapak Suparno melakukan pinjaman yang lebih besar dari pada Bapak Zainal, otomatis ujrahnya juga lebih besar. Akan tetapi Bapak Suparno menyadari bahwa BMT juga merupakan lembaga keuangan di mana BMT juga ingin mendapatkan keuntungan. ${ }^{33}$

Peminjam diharuskan mengembalikan hutang pokok pada waktu yang telah ditentukan, baik dengan cara mengangsur atau dengan cara dibayar tunai. BMT UGT Sidogiri Cabang Waru Sidoarjo memberikan pembiayaan menggunakan akad rahn dan ija $\triangleright a h$ dengan tujuan daripada peminjam terjatuh di tangan rentenir yang memberikan hutang dengan menerapkan bunga yang lebih besar dan merupakan riba yang diharamkan dalam syariat Islam. ${ }^{34}$

\section{Studi Fatwa Dewan Syariah Nasional (DSN) tentang Aplikasi Penetapan Ujrah dalam Akad Rahn di BMT UGT Sidogiri Cabang Waru Sidoarjo}

Dewan Syariah Nasional (DSN) merupakan sebuah lembaga yang berada di bawah naungan Majelis Ulama Indonesia (MUI), yang dipimpin oleh Ketua Umum MUI. Fungsi utama Dewan Syariah Nasional (DSN) adalah mengawasi produk-produk lembaga keuangan syariah agar sesuai dengan syariat Islam. Untuk keperluan pengawasan, Dewan Syariah Nasional (DSN) membuat garis panduan pada produk syariah yang diambil dari sumbersumber hukum Islam. Garis panduan ini menjadi dasar pengawasan bagi Dewan Syariah Nasional (DSN) pada lembaga-lembaga keuangan syariah dan menjadi dasar pengembangan produk-produknya. Garis panduan pada produk syariah adalah fatwa Dewan Syariah Nasional (DSN). Fatwa Dewan Syariah Nasional (DSN) merupakan Peraturan dan ketentuan yang berkenaan dengan semua kegiatan dalam lembaga keuangan syariah.

Dalam BMT UGT Sidogiri Cabang Waru Sidoarjo tidak menganut sistem bunga, namun lebih menggunakan biaya jasa, sebagai penerimaan dan labanya, yang dengan pengenaan biaya jasa itu paling tidak dapat menutupi seluruh biaya yang dikeluarkan dalam operasionalnya. Oleh karena itu, untuk menghindari adanya unsur riba (bunga) dalam gadai syariah dalam usahanya pembentukan laba, maka gadai syariah menggunakan mekanisme yang sesuai dengan prinsip-prinsip syariah, seperti melalui akad qard\}al-hłsan dan akad

\footnotetext{
${ }^{31}$ Zainal, Nasabah BMT UGT Sidogiri Cabang Waru Sidoarjo, Wawancara, Sidoarjo, 30 Juni 2014.

${ }^{32}$ Suparno, Nasabah BMT UGT Sidogiri Cabang Waru Sidoarjo, Wawancara, Sidoarjo, 29 Juni 2014.

33 Ibid.

${ }^{34}$ Mustakim, Wawancara, Sidoarjo, 29 juni 2014.
} 


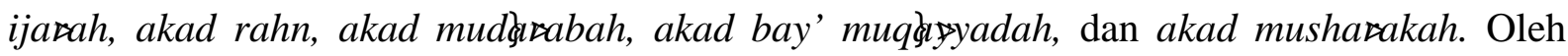
karena itu, pendapat bahwa gadai ketika sebagai sebuah lembaga keuangan, maka fungsi sosialnya perlu dipertimbangkan lagi, apalagi fungsi sosial gadai itu dihilangkan, tidak sepenuhnya benar. Karena paling tidak ada dua alasan bahwa dengan terlembaganya gadai, bukan berarti menghilangkan fungsi sosial gadai itu, yang berdasarkan hadis-hadis yang mendasarinya menunjukkan bahwa fungsi gadai itu memang untuk fungsi sosial. Alasan itu adalah:

1. Dengan terlembaganya gadai, pegadaian tetap dapat mendapatkan penerimaan dari pihak rałin, berupa biaya administrasi dan biaya jasa lainnya, seperti jasa penyimpanan dan pemeliharaan. Berarti pegadaian tidak dirugikan.

2. Fungsi sosial tersebut masih diperlukan guna membantu masyarakat yang membutuhkan dana yang sifatnya mendesak, terutama untuk keperluan hidup sehari-hari, seperti dalam kasus Rasulullah yang menggadaikan baju besinya demi untuk mendapatkan bahan makanan.

Penentuan besarnya ujrah di BMT UGT Sidogiri Cabang Waru Sidoarjo ditentukan berdasarkan besarnya jumlah pinjaman tetapi yang membedakan perbedaan biaya yang dikenakan antara satu nasabah dengan nasabah yang lain dalam menggadaikan barang dengan nilai taksiran yang sama tetapi jumlah pinjaman berbeda adalah adanya diskon ijazah yang diberikan karena nasabah meminjam dibawah harga pinjaman. Jadi terlihat sekali bahwa perhitungan biaya ijazah atau biaya sewa tempat bukan dilihat dari jumlah pinjaman nasabah, berarti dalam penentuan biaya ujrah di BMT tidak sesuai dengan Fatwa Dewan Syariah Nasional Nomor 25/DSN- MUI/III/2002 yaitu bahwa besar biaya pemeliharaan dan penyimpanan marhuæ tidak boleh ditentukan oleh jumlah besar pinjaman.

Dalam aplikasi penetapan ujrah dalam akad rahn di BMT UGT Sidogiri Cabang Waru Sidoarjo. Bapak Zainal dan Bapak Suparno, beliau berdua melakukan pinjaman kepada pihak BMT dengan jumlah pinjaman yang berbeda dan membawa barang jaminan yang sama, Bapak Zainal sendiri melakukan pinjaman sebesar Rp. 5.000.000.- sedangkan Bapak Suparno melakukan pinjaman sebesar Rp. 7.000.000.- dari situ sudah terdapat perbedaan dari segi jumlah pinjaman. Pihak BMT sendiri kemudian melakukan penaksiran kepada kedua nasabah tersebut, Bapak Zainal yang melakukan pinjaman lebih kecil mendapatkan diskon dari pihak BMT, karena melakukan pinjaman lebih kecil dari pada Bapak Suparno, hal tersebut tidak sesuai dengan fatwa Dewan Syariah Nasional Nomor 25/DSN-MUI/III/2002.

Meskipun aplikasi penetapan ujrah dalam akad rahn ini tidak sesuai dengan fatwa DSN Nomor 25/DSN-MUI/III/2002 tentang rahn, namun niat baik BMT UGT Sidogiri Cabang Waru Sidoarjo patut diapresiasi (diberi respon yang positif) memberikan pembiayaan menggunakan akad rahn dan ija aah dengan tujuan daripada peminjam terjatuh di tangan rentenir yang memberikan hutang dengan menerapkan bunga yang lebih besar dan merupakan riba yang diharamkan dalam syariat Islam. Yakni adanya unsur tolong menolong agar ikatan akadnya bisa segera selesai, hal ini didasarkan pada firman Allah dalam sebagai berikut:

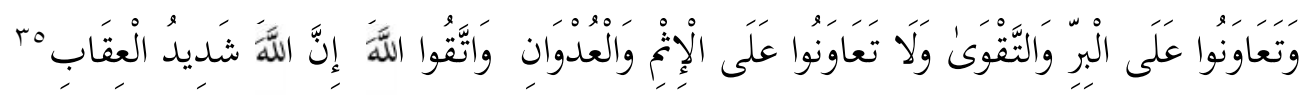

${ }^{35}$ al-Quran, 5: 2. 
"Dan tolong menolonglah kamu dalam (mengerjakan) kebajikan dan taqwa, dan jangan tolong-menolonglah dalam berbuat dosa dan permusuhan dan bertakwalah kamu kepada Allah, Sesungguhnya Allah amat berat siksa-Nya." 36

Prinsip tolong-menolong dalam akad rahn, sebagaimana telah dijelaskan dalam akad tabarru', namun demikian BMT UGT Sidogiri Cabang Waru Sidoarjo juga dituntut eksis mengingat telah dipercaya oleh Pemodal dalam hal ini Bank Muamalat Indonesia (BMI) dan mengembalikan modal dari lembaga tersebut dengan prinsip saling menguntungkan, jadi hal ini semakin memperjelas akad ijazah yang merupakan unsur utama dalam keberlangsungan perum pegadaian itu sendiri.

Pada aplikasi penetapan ujrah dalam akad rahn, pihak BMT UGT Sidogiri Cabang Waru Sidoarjo adalah lembaga keuangan yang dituntut untuk mengembalikan modalnya, maka dalam pelaksanaanya pihak pegadaian melakukan terobosan dengan adanya diskon ija $a h$, dimana fungsi diskon ini sendiri untuk menarik minat nasabah. Tarif diskon ija $a h$ di BMT UGT Sidogiri Cabang Waru Sidoarjo berlaku bila rałin (nasabah) meminjam uang lebih kecil.

Dengan melihat realisasi penetapan ujrah dalam akad rahn, nasabah yang melakukan pembiayaan rahn di BMT UGT Sidogiri Cabang Waru Sidoarjo, Pada dasarnya nasabah harus menyerahkan barang sebagai jaminan untuk memperoleh pinjaman dari pihak BMT, dan Peminjam diharuskan mengembalikan hutang pokok pada waktu yang telah ditentukan, baik dengan cara mengangsur atau dengan cara dibayar tunai. Dalam penetapan ujrah, meskipun barang yang diserahkan nasabah kepada pihak BMT itu sama dalam harga jual dipasaran, akan tetapi tidak menjadi patokan dalam penetapan ujrahnya, karena pihak BMT melakukan penetapan ujrah berdasarkan atas jumlah pinjaman yang dilakukan oleh nasabah.

\section{Kesimpulan}

Berdasarkan dari penelitian yang dilakukan penulis, maka penulis dapat memberikan kesimpulan sebagai berikut:

1. Aplikasi penetapan ujrah dalam akad rahn di BMT UGT Sidogiri Cabang Waru Sidoarjo yakni penetapan ujrah melalui dua akad yakni akad rahn dan ijaðah. Prosedur pelaksanaan akad keduanya adalah sebagai berikut: rałin (nasabah) mendatangi murtahin (BMT) sambil menyerahkan marhuæ (barang jaminan) kemudian barang akan ditaksir. Akibat dari ini maka rałin akan dikenai biaya administrasi. Kemudian ratein menandatangani perjanjian atau akad rahn setelah itu untuk menitipkan barang gadaiannya rałin harus melaksanakan akad ija ah (akad untuk sewa tempat), akibatnya akan timbul ujrah. Dalam hal ini berarti nasabah harus melaksanakan dua rentetan akad. Dan peminjam diharuskan mengembalikan hutang pokok pada waktu yang telah ditentukan, baik dengan cara mengangsur atau dengan cara dibayar tunai.

2. Aplikasi penetapan ujrah yang dilaksanakan di BMT UGT Sidogiri Cabang Waru Sidoarjo. Penetapan ujrah yang diterapkan di BMT UGT Sidogiri Cabang Waru Sidoarjo tidak sesuai dengan fatwa DSN-MUI Nomor 25/DSN-MUI/III/2002 karena penetapan

\footnotetext{
${ }^{36}$ Departemen Agama RI, Al-Qur'an dan Terjemahannya, 156-157.
} 
ujrah ditentukan dari jumlah pinjaman nasabah, sedangkan yang membedakan perbedaan tarif adalah adanya diskon yang diberikan kepada nasabah karena mengajukan pinjaman yang lebih kecil. Penentuan diskon pun ditentukan dari ujrah atau biaya ija ăh yang dikenakan pada nasabah. Diskon ini dihitung sesuai prosentase nilai taksiran jumlah pinjaman nasabah.

\section{Daftar Rujukan}

Antonio, Muhammad Syafi'i. Bank Syariah Dari Teori Ke Praktik. Jakarta: Gema Insani, 2009.

Bank Indonesia. Petunjuk Pelaksanaan Pembukaan Kantor Bank Syariah. Jakarta: Bank Indonesia, 1999.

Barlinti, Yeni Salma. Kedudukan Fatwa Dewan Syariah Nasional dalam Sistem Hukum Nasional di Indonesia. Jakarta: Badan Litbang dan Diklat Kementerian Agama RI, 2010 .

Basir, Ahmad Azhar. Hukum Islam Tentang Riba, Utang Piutang Gadai”. Bandung: alMa'arif, 1983.

Departemen Agama RI. Al-Qur'an dan Terjemahannya. Jakarta: Widya Cahaya, 2009.

Nawawi, Ismail. Fiqh Muamalah. Surabaya: Vira Jaya Multi Press, 2009.

Ridwan, Muhammad. Manajemen Baitul Maal Wa Tamwil (BMT). Yogyakarta: UII Press, 2005.

Sjahdeini, Sutan Remi. Perbankan Islam dan Kedudukannya Dalam Tata hukum Perbankan Indonesia. Jakarta: Pustaka Utama Grafita, 1999.

Subagio. Bank dan Lembaga Keuangan Lainnya. Yogyakarta: Bagian Penerbitan Sekolah Tinggi Ilmu Ekonomi YKPM, 1997.

Suhendi, Hendi. Fiqih Muamalah. Jakarta: Raja Grafindo Persada, 2005.

Widodo, Hertanto dkk. Panduan Praktis Operasional Baitul Mal Wat Tamwil (BMT). Bandung, Mizan, 1999.

Yunus, Jamal Lulail. Manajemen Bank Syariah Mikro. Malang: UIN-Malang Press, 2009. 